\title{
ASSESSMENT OF LANDFILL GAS (LFG) ENERGY POTENTIAL BASED ON ESTIMATES OF LFG MODELS
}

\author{
(DEPO GAZI ENERJI POTANSIYYLLININ DEPO GAZI MODELLERI \\ TAHMINLERINE DAYANARAK BELIRLENMESI)
}

\author{
Hasan SARPTAŞ ${ }^{1}$
}

\begin{abstract}
Methane emission from landfilling of waste is one of the most prevalent gas contributing to the greenhouse effect. Current waste management strategies, aim to reduce methane emissions from landfills, promote energy recovery from landfill gas (LFG) that is recognized as a renewable energy resource, due to its higher calorific value. First and the most crucial stage in the planning and design of LFG collection and energy recovery systems is to quantify LFG generation. It's because, the quantity of LFG and its methane content determine both the applicable method for the control and use of LFG and the feasibility of energy recovery. LFG models are developed for the projection of LFG generation over time from a mass of landfilled waste. During planning and projection phase of a landfill, the amount of gas that will be generated and recovered at the site can be estimated - based on projected amounts of waste - by only using these models. Due to complex nature of LFG formation, several models have been developed to model and estimate LFG generation with different approaches for regions in different climates. In a LFG energy recovery project, selection of the appropriate modeling approach and its model parameters for the estimation of LFG generation is the most crucial step. With considering this requirement, this study aims to estimate the amount of LFG and its technical energy potential from the case study landfill site (i.e. Harmandalı Landfill Site in İzmir Metropolitan City). According to the computations carried out by Multi-phase model, it was determined that the remaining amount of LFG at the site was nearly $50 \%$ of total energy potential. Besides, maximum energy potential from LFG generated at the site was estimated as 9.6 MW. This study indicates that LFG models can be utilized as effective tools in energy recovery projects.
\end{abstract}

Keywords: landfill gas, LFG, estimation, modelling, energy potential

\section{$\ddot{O} Z$}

Katı atık depolama sahalarında oluşan metan, sera etkisine yol açan başlıca gazlardan biridir. Katı atık depolama sahalarından metan salınımlarının azaltılmasını amaçlayan mevcut atık yönetim stratejileri, yüksek kalorifik değeri nedeniyle yenilebilir enerji kaynă̆ı olarak kabul edilen depo gazından enerji geri kazanımını teşvik etmektedir. Depo gazı toplama ve enerji geri kazanımı sistemlerinin planlama ve tasarımında ilk ve en kritik aşama, oluşan depo gazı miktarını belirlemektir. Çünkü depo gazı miktarı ve gazın metan içeriği, hem depo gazının kontrolü ve kullanımı için uygulanabilir yöntemi hem de enerji geri kazanımının fizibilitesini belirler. Depo gazı modelleri, depolanan bir atık kütlesinden belli bir zamanda oluşacak depo gazı miktarının kestirimi amacıyla geliştirilmişlerdir. Bir depolama sahasının planlanması veya projelendirilmesi safhasında, oluşacak depo gazı miktarı ancak bu modeller yoluyla - depolanacak atık miktarı tahminleri kullanılarak hesaplanabilir. Depo gazı oluşumunun karmaşık yapısı nedeniyle, farklı iklim bölgeleri için veya farklı yaklaşımlarla çok sayıda model geliştirilmiştir. Depo gazından enerji geri kazanımı projelerinde, depo gazının bir matematiksel model yaklaşımı ile hesaplanması için uygun model yaklaşımının belirlenmesi ve modele ait

\footnotetext{
${ }^{1}$ Ege Üniversitesi, Güneş Enerjisi Enstitüsü, Güneş Enerjisi Bölümü, İzmir, hasan.sarptas @ ege.edu.tr
} 
parametrelerin seçimi kritik öneme sahiptir. Bu noktadan hareketle, bu çalışmada, seçilen depo gazı modelleri (Tabasaran \& Rettenberger, TNO, LandGEM ve Multi-phase modelleri) ile örnek depolama sahasl olarak seçilen İzmir Harmandalı Depolama Sahası'nda oluşacak depo gazı miktarının ve depo gazından elde edilebilecek teknik enerji potansiyelinin belirlenmesi amaçlanmıştır. Çalışmada Multi-phase modeli ile yapılan hesaplamalara göre, sahada 2016 yll sonrast için kullanılabilir enerji potansiyelinin toplam enerji potansiyelinin \%50'sine yakın seviyede olduğu belirlenmiştir. Ayrıca sahadan çıkan depo gazı ile elde edilebilecek en yüksek enerji potansiyeli 9.6 MW olarak hesaplanmıştır. Bu çalışma, depo gazı modellerinin enerji geri kazanım projelerinde etkin bir araç olarak kullanilabileceğini ortaya koymuştur.

Anahtar Kelimeler: depo gazl, tahminleme, modelleme, enerji potansiyeli

\section{INTRODUCTION}

The most challenging stage in the planning and design of landfill gas (LFG) systems is to identify the amount of LFG that can be generated in the landfill site. The design requirements of a gas collection and control system and the applicable method for the control and/or use of LFG are determined based on the amount of LFG and its methane content. Similarly, these characteristics of LFG are essential parameters for identifying the feasibility of energy recovery systems [1] [2].

In active landfill sites, LFG emissions can be identified by field measurements (i.e. measuring LFG flows and composition at test wells in the site). While field measurement provides more accurate results about LFG generation, it is time-consuming and expensive process. So, mathematical modeling approaches have been developed to estimate LFG generation and recovery based on past and/or future waste quantities. But, in planning phase of a landfill project, the use LFG models is the only way to determine the amount of LFG generation [1].

The total volume of LFG generated at a landfill site depends on waste characteristics (quantity, age and organic waste content of landfilled waste) and site conditions (temperature, moisture content and etc.). Gas collection system efficiency must be considered to calculate the actual amount of LFG collected at the site. There exist numerous factors controlling LFG formation at the site and these factors greatly varies by climate, time and location. Therefore, several modeling approaches using different assumptions have been developed to model and estimate LFG generation for different regions in different climates [7] [8]. Early models such as EPER Germany, SWANA Zero Order and IPCC - are classified under zero-order models that methane generation is assumed as constant over time. But, this assumption causes a crucial inaccuracy in the results. Most of the models are based on Monod first-order decay equation and are called as first-order decay models - such as LandGEM, SWANA, TNO, GasSim. First-order models have a linear relationship with maximum potential of methane production per unit weight of waste and an exponential relationship with decay rate and time [3] [7] [8].

Since energy potential is directly influenced by the volume of LFG, technical energy potential from LFG collected at a landfill site can be assessed by utilizing the results of LFG modeling study. But, as stated earlier, there exist several approaches for the estimation of LFG generation presently; and there is no special mathematical modeling approach developed to use in landfill projects in most countries such as Turkey. Thus a crucial issue in the design of a LFG energy recovery project is to select the appropriate modeling approach and its model parameters for the estimation of LFG generation. With considering this requirement, this study aims to examine commonly applied LFG models in terms of estimation approaches and model outputs and to estimate technical energy potential from a case landfill site. In the 
previous study [11], the LandGEM, Tabasaran \& Rettenberger and Multi-phase models have been compared in terms of prediction of LFG generation. The presented study uses an additional model (TNO model) to estimate LFG generation. It's because this study also aims to compare TNO model and Multi-phase model, both developed in the same approach by using actual site data.

In this study Harmandalı Landfill Site in İzmir Metropolitan City was selected as the case study area. While the site has been also selected as case area in previous work [11], calculations have been performed only for the lot E, i.e. active lot operated since 2007; and LFG volumes have been estimated by only waste deposited in the site for the years 2007 to 2010. But this study was carried out for the whole site; and LFG estimates and energy potential calculations were performed by assuming that the site will be operated up to 2020 (Section 2.1).

While the main focus area of previous study was prediction of LFG generation, this study also enhances the estimation by (i) expressing the method used for energy potential calculations from LFG volume; (ii) identifying gross and net energy potential terms; and (iii) providing parameters of energy potential equations and defines their possible ranges.

\section{MATERIALS AND METHODS}

\subsection{Description of the Study Area}

Harmandal1 Landfill Site, inaugurated in April 1992, was designed to serve the city for 20 years. The site, approximately $25 \mathrm{~km}$ far away from the city center, has active storage about 23 ha. Since a new solid waste disposal facility is under planning stage in İzmir, it's reasonable to consider that the site will continue to be operated until 2020. Waste acceptance rates given in Table 1 for the years 1992 to 2010 are actual site data, obtained from the Municipality. The amount of waste deposited at the site for years $2011-2020$ were projected based on the trend in existing waste acceptance rates.

In 2010, a total of 1,100,000 ton of solid waste, of which 1,025,000 tons is domestic waste, was stored in the site [4]. The amount of solid waste generated in İzmir is approximately 3400 tons/day in 2015; and approximately $95 \%$ of generated solid waste is disposed in the site. Waste composition were determined based on waste characteristics obtained from İzmir Municipality for the years 2008 and 2009 (Table 2). Composition of solid waste for each year have been determined as the average of seasonal measurements carried out for summer and winter. 
Table 1. The amount of waste deposited in Harmandalı Landfill Site in 1992-2020.

\begin{tabular}{|c|c|c|c|}
\hline Year & $\begin{array}{c}\text { Amount } \\
\text { (ton/year) }\end{array}$ & Year & $\begin{array}{c}\text { Amount } \\
\text { (ton/year) }\end{array}$ \\
\hline 1992 & 122,520 & 2007 & 805,959 \\
\hline 1993 & 165,300 & 2008 & 935,309 \\
\hline 1994 & 192,201 & 2009 & $1,036,334$ \\
\hline 1995 & 376,400 & 2010 & $1,037,951$ \\
\hline 1996 & 486,945 & 2011 & $1,074,900$ \\
\hline 1997 & 541,870 & 2012 & $1,120,100$ \\
\hline 1998 & 575,240 & 2013 & $1,165,400$ \\
\hline 1999 & 654,760 & 2014 & $1,210,600$ \\
\hline 2000 & 644,800 & 2015 & $1,255,900$ \\
\hline 2001 & 689,870 & 2016 & $1,301,100$ \\
\hline 2002 & 674,430 & 2017 & $1,346,400$ \\
\hline 2003 & 642,130 & 2018 & $1,391,600$ \\
\hline 2004 & 681,440 & 2019 & $1,436,900$ \\
\hline 2005 & 718,550 & 2020 & $1,482,100$ \\
\hline 2006 & 842,550 & & \\
\hline & & & \\
\hline
\end{tabular}

\subsection{Description of the Models}

Tabasaran \& Rettenberger model defines the cumulative amount of gas produced during a certain time and simulates carbon degradation by a first order decay approach given in Eq 1. The expression in the model is a relationship originally developed for the anaerobic digestion of sewage. Due to the portion of substrate, used for cell synthesis, may vary with temperature in sewage digestion, the model equation contains a temperature correction in the $G_{e}$ determination. However, anaerobic digestion in landfills is different as compared to anaerobic digesters, the temperature correction is irrelevant for landfills [5].

$G_{t}=1.868 \cdot C_{\text {org }} \cdot(0.014 \cdot T+0.28) \cdot\left(1-10^{-k \cdot t}\right) \cdot M_{t}$

$T$ : The temperature $\left({ }^{\circ} \mathrm{C}\right)$

$C_{\text {org }}$ : Organic carbon in waste $(\mathrm{kg} \mathrm{OC} /$ ton waste)

$k$ : Degradation rate constant $\left(\mathrm{y}^{-1}\right)$

$M_{t}$ : The amount of waste in $\mathrm{t}$ years

$G_{t}:$ Total LFG production in t years $\left(\mathrm{m}^{3}\right)$

The suggested model parameters for Tabasaran \& Rettenberger model are (i) $25-40{ }^{\circ} \mathrm{C}$ for temperature, $170-220 \mathrm{~kg} /$ ton-waste for amount of organic carbon; and 0,025 - 0,050 $\mathrm{y}^{-1}$ for methane generation rate [6].

The TNO model, development by the Dutch research institute TNO in 1994, is the first model, where model parameters were based on real data of landfill gas generation at a larger group of landfills. The model calculates LFG production based on the degraded organic 
carbon in the waste. The effect of depletion of carbon in the waste through time is accounted for in a first-order model. LFG formation from a certain amount of waste is assumed to decay exponentially in time. The first-order model can be described mathematically by Eq 2 [7] [8].

$G_{t}=d \cdot 1.87 \cdot M \cdot C_{\text {org }} \cdot k \cdot e^{-k \cdot t}$

$M$ : The amount of waste in place (ton)

$C_{\text {org: }}$ Organic carbon in waste (kg OC/ton waste)

$k$ : Degradation rate constant $\left(\boldsymbol{k}=\mathbf{0 . 0 9 4} \mathrm{y}^{-1}\right)$

d : Dissimilation factor

$G_{t}:$ LFG production at a given time $\left(\mathrm{m}^{3} /\right.$ year $)$

Amount of organic carbon in waste $\left(C_{\text {org }}\right)$ has been classified in 8 categories. The categories and their organic carbon contents have been defined as $11 \mathrm{~kg}$ OC/ton for contaminated soil and construction and demolition waste, $90 \mathrm{~kg}$ OC/ton for street cleansing waste and sewage sludge and compost, $111 \mathrm{~kg}$ OC/ton for commercial waste and $130 \mathrm{~kg}$ OC/ton for shredder waste, coarse household waste and household waste.

LandGEM model uses the first order decay model to simulate annual LFG emissions over certain time. Simplified mathematic expression is given in Eq. 3 [2].

$Q_{C H 4}=k \cdot L_{0} \cdot \sum_{i=1}^{n} M_{i} \cdot e^{-k \cdot t_{i}}$

$L_{0} \quad$ : Potential methane generation capacity $\left(\mathrm{m}^{3} \mathrm{CH}_{4} /\right.$ ton waste $)$

$k \quad$ : Degradation rate constant $\left(\mathrm{y}^{-1}\right)$

$n \quad:$ The number of the years for gas generation

$M_{i} \quad$ : Mass of waste disposed in the $\mathrm{i}^{\text {th }}$ year (ton/y)

$Q_{C H 4}$ : Estimated methane generation flowrate $\left(\mathrm{m}^{3} / \mathrm{y}\right)$

Multi-phase model (Afvalzorg), based on TNO model, estimates amount of LFG on the basis of biologically degradable organic carbon ratio in the waste and the cumulative amount of waste. It assumes that different types of waste contain different fractions of organic matter that degrade at different rates. The advantage of a multi-phase model is that the typical waste composition can be taken into account. In the Multi-phase model, eight waste categories and three fractions are distinguished. Rate constants for slow, moderate, and rapid degrading fractions are $0.030 \mathrm{y}^{-1}, 0.099-0.116 \mathrm{y}^{-1}$ and $0.187-0.231 \mathrm{y}^{-1}$ respectively. The multi-phase model describes that kitchen waste degrades much faster than wood or paper. The multi-phase model is a first-order model and can be described mathematically by Eq. 4 [7].

$G_{t}=d \cdot 1.87 \cdot M \cdot \sum_{i=1}^{3} C_{0, i} \cdot k_{i} \cdot e^{-k_{i} \cdot t}$

$M:$ The amount of waste in place (ton)

$C_{0, i}$ : Organic carbon in waste fraction i ( $\mathrm{kg} \mathrm{OC} / \mathrm{ton}$ waste)

$k_{i}$ : Degradation rate constant for waste fraction i $\left(\mathrm{y}^{-1}\right)$

d : Dissimilation factor $(0.58-0.80)$

$G_{t}:$ LFG production at a given time $\left(\mathrm{m}^{3} /\right.$ year $)$ 


\subsection{Determination of LFG Model Parameters}

The model parameters for the selected models were determined based on existing data and information regarding the landfill site (i.e. waste composition, known site conditions) and a review of relevant literature on LFG models.

Methane Content: According to the field measurements carried out by our previous study [4] in the 73 gas collection wells in the site, methane content of LFG generated has been determined as approximately $\mathbf{5 0 \%}$.

Potential Methane Generation Capacity $\left(L_{0}\right)$ and LFG Generation Rate $(k)$ : In this study, model parameters for the case landfill site, were identified by the approach developed by CRA [9]. Guidelines by CRA segregated waste stream into three categories for selecting site-specific LFG generation model parameters: (1) relatively inert, such as metal, glass, plastic, and soil; (2) moderately decomposable, such as paper, wood, wooden furniture, rubber, textiles, and construction and demolition material, and (3) decomposable such as food waste, yard waste, and slaughterhouse waste [9]. Each category of waste has a different potential for methane generation (Table 3).

Table 3. Waste characterization and potential methane capacity [9]

\begin{tabular}{|c|l|c|}
\hline ID & \multicolumn{1}{|c|}{ Waste Category } & $\boldsymbol{L}_{\boldsymbol{\theta}}\left(\mathbf{m}^{\mathbf{3}} / \mathbf{t o n}\right)$ \\
\hline 1 & Relatively inert & 20 \\
\hline 2 & Moderately decomposable & 120 \\
\hline 3 & Decomposable & 160 \\
\hline
\end{tabular}

The value of LFG generation rate $(k)$ is influenced by moisture content of waste stream, the availability of nutrients, $\mathrm{pH}$, and temperature. So, the $k$ value should be selected based on annual average precipitation and waste composition. This evaluation can be easily done by using the $k$ value selection matrix given by CRA [9] (Table 4).

Table 4. The $k$ value selection matrix [9]

\begin{tabular}{|r|c|c|c|}
\hline $\begin{array}{c}\text { Precipitation } \\
(\mathbf{m m} / \mathbf{y})\end{array}$ & $\begin{array}{c}\text { Relatively } \\
\text { Inert }\end{array}$ & $\begin{array}{c}\text { Moderate } \\
\text { Decomposable }\end{array}$ & Decomposable \\
\hline$<250$ & 0.01 & 0.01 & 0.03 \\
\hline $250-500$ & 0.01 & 0.02 & 0.05 \\
\hline $500-1,000$ & 0.02 & 0.04 & 0.09 \\
\hline $1,000-2,000$ & 0.02 & 0.06 & 0.11 \\
\hline $2,000-3,000$ & 0.03 & 0.07 & 0.12 \\
\hline$>3,000$ & 0.03 & 0.08 & 0.13 \\
\hline
\end{tabular}

Average annual precipitation in the region for the period of $1971-2013$ is about 688.5 $\mathrm{mm}$ [10]. Weighted waste category no. or ID for the site was calculated as 2.2 ; thus the waste deposited on the site was considered as nearly moderate decomposable.

Potential methane capacity and LFG generation rate $(k)$ for Harmandalı landfill site were 
calculated as $\boldsymbol{L}_{\boldsymbol{0}}=\mathbf{1 0 9} \mathrm{m}^{3} \mathbf{C H} /$ ton MSW and $\boldsymbol{k}=\mathbf{0 . 0 5 8}$ based on waste characteristics given in Table 2. In this calculation, the waste categorization identified by CRA [9] was applied and $L_{0}$ and $k$ values were calculated by weighted sum (Table 5).

Table 5. Calculation of methane potential

\begin{tabular}{|c|c|c|c|c|}
\hline Waste Type & Content (\%) & Cat. ID & $L_{0}\left(m^{3} /\right.$ ton $)$ & $k$ \\
\hline Kitchen waste & 44.42 & 3 & 71.07 & 0,002 \\
\hline Garden waste & 2.91 & 3 & 4.66 & 0,003 \\
\hline Paper & 7.46 & 2 & 8.95 & 0,001 \\
\hline Cardboard & 4.57 & 2 & 5.48 & 0,000 \\
\hline Other combustible & 10.67 & 2 & 12.80 & 0,004 \\
\hline Plastics & 7.73 & 1 & 1.55 & 0,000 \\
\hline Glass & 5.18 & 1 & 1.04 & 0,000 \\
\hline Metal & 1.09 & 1 & 0.22 & 0,001 \\
\hline WEEE & 0.10 & 1 & 0.02 & 0,000 \\
\hline Hazardous waste & 0.43 & 1 & 0.09 & 0,002 \\
\hline Other non-comb. & 6.45 & 1 & 1.29 & 0,002 \\
\hline Others & 0.50 & 1 & 0.10 & 0,040 \\
\hline \multirow[t]{2}{*}{ Ash and Fines } & 8.49 & 1 & 1.70 & 0,003 \\
\hline & & Total & 108.96 & 0.058 \\
\hline
\end{tabular}

Organic Carbon Content $\left(\boldsymbol{C}_{\text {org }}\right)$ : As shown in their mathematical expressions, TNO, Tabasaran \& Rettenberger and Multi-phase models use organic carbon content $\left(C_{\text {org }}\right)$ in waste stream for methane potential estimation whereas LandGEM model calculates methane/LFG potential based on potential methane generation capacity $\left(L_{0}\right)$, described in Table 3 . These parameters can be converted to each other by applying stoichiometric conversion. As stated by Scharff \& Jacobs, $1 \mathrm{~kg}$ degraded organic carbon (OC) produces $0.933 \mathrm{~m}^{3}$ of $\mathrm{CH}_{4}$; thus, $L_{0}$ theoretically can be expressed as $L_{0}=0.933 \cdot C_{\text {org }}$ [7]. In order to better comparison of models, organic carbon parameter for TNO and Tabasaran \& Rettenberger model was calculated as $C_{\text {org }}=117 \mathrm{~kg}$ OC/ton MSW based on calculated potential methane generation capacity of 109 $\mathrm{m}^{3} \mathrm{CH}_{4} /$ ton MSW.

For Tabasaran \& Rettenberger model, average temperature at the site was considered as $\mathbf{T}=\mathbf{3 0}^{\circ} \mathbf{C}$. LFG generation rate $(k)$ was calculated as $\boldsymbol{k}=\mathbf{0 . 0 3 4} \mathbf{y}^{\mathbf{- 1}}$ with considering $k$ values and the range for $k$ values identified in Table 4 .

In TNO model, dissimilation factor was assumed as 0.70 based on case studies given in [7]. And organic carbon content was selected as $90 \mathrm{~kg}$ OC/ton with considering waste composition.

For Multi-phase model, the values of model parameters were chosen considering to existing deposited waste, its fraction, amount and volume as well as the water content. Considering waste characterization, $k_{i}$ for fast, moderate and slow degrading waste types was 
chosen as $0.125 \mathbf{y}^{-1}, \mathbf{0 . 0 7 5} \mathbf{y}^{-1}$ and $\mathbf{0 . 0 3} \mathbf{y}^{-1}$, respectively. Organic carbon content ( $C_{o, i}$ values) for fast, moderate and slow degrading waste types was calculated as $\boldsymbol{C}_{\boldsymbol{o}, \boldsymbol{I}}=\mathbf{1 6 0} \mathbf{k g} / \mathbf{t o n}, \boldsymbol{C}_{\boldsymbol{o}, \boldsymbol{2}}$ $=120 \mathrm{~kg} /$ ton and $\boldsymbol{C}_{\boldsymbol{o}, 3}=\mathbf{2 0} \mathrm{kg} / \mathrm{ton}$, respectively, based on $L_{0}$ values considered for different waste categories given in Table 3. Dissimilation factor was assumed as $\boldsymbol{d = 0 . 7 0}$ [11].

Table 6. Model parameters

\begin{tabular}{|c|c|c|c|c|c|c|c|c|c|}
\hline Model & \multicolumn{3}{|c|}{$k$ (Half-Life) } & $L_{0}$ & \multicolumn{3}{|c|}{$C_{\text {org }}$} & $T$ & $d$ \\
\hline LandGEM & \multicolumn{3}{|c|}{$0.058(17.2)$} & 109 & \multicolumn{3}{|c|}{-} & - & - \\
\hline Tab.\&Ret. & \multicolumn{3}{|c|}{$0.034(29.4)$} & - & \multicolumn{3}{|c|}{117} & 30 & - \\
\hline TNO & \multicolumn{3}{|c|}{0.094 (10.6) } & - & \multicolumn{3}{|c|}{90} & - & 0.7 \\
\hline \multirow[b]{2}{*}{ Multi-Phase } & Fast & Mod. & Slow & \multirow[b]{2}{*}{-} & Fast & Mod. & Slow & \multirow[b]{2}{*}{-} & \multirow[b]{2}{*}{0.7} \\
\hline & $\begin{array}{c}0.125 \\
(8)\end{array}$ & $\begin{array}{c}0.075 \\
(13)\end{array}$ & $\begin{array}{c}0.030 \\
(33)\end{array}$ & & 160 & 120 & 20 & & \\
\hline
\end{tabular}

\subsection{Energy Potential of LFG}

Energy Content: Energy content of LFG varies by gas quality. It's typically $\mathbf{1 6} \mathbf{- 2 0}$ $\mathbf{M J} / \mathbf{m}^{\mathbf{3}}$ for low and medium-quality LFG whereas high quality LFG produced by effective pretreatment can have up to $\mathbf{3 0} \mathbf{M J} / \mathbf{m}^{\mathbf{3}}$ [4] [12] [13].

Conversion Efficiency for Electricity Production: After pretreatment, LFG can be converted to electricity by a number of techniques in terms of LFG energy content. Conversion efficiency for these techniques are $25 \%-30 \%$ for gas turbines, steam turbines and microturbines and $28 \%$ - $40 \%$ for reciprocating gas engines [4].

Capacity Factor: Capacity factors for biomass energy systems ranges in $80 \%$ to $90 \%$.

Gross and Net Energy Potential: Gross energy potential can be calculated based on the volume of LFG collected and its energy content (Eq. 5).

$$
G E P=\eta_{g c} \cdot E C \cdot G_{t}
$$

GEP : Gross energy potential $(\mathrm{kWh})$

$\eta_{g c} \quad$ : Gas collection efficiency (-)

$E C \quad$ : Energy content $\left(\mathrm{kWh} / \mathrm{m}^{3}\right)$

$G_{t} \quad$ : The volume of LFG identified by LFG modelling $\left(\mathrm{m}^{3}\right)$

Net energy potential derived from LFG energy recovery system can be calculated by considering capacity factor conversion efficiency for electricity generation (Eq. 6).

$N E P=\left(\eta_{e c} \cdot G E P\right) /(C F \cdot 8760)$

$N E P$ : Net energy potential $(\mathrm{kWh})$

$\eta_{e c}:$ Electricity conversion efficiency (-)

$C F$ : Capacity Factor (-) 


\section{RESULTS AND DISCUSSIONS}

The results (i.e. total and remaining LFG potential) are given in Table 7 and variation of LFG generation by years obtained by each model is given in Figure 1.

This case study clearly shows a huge difference in LFG/methane emission estimations obtained from four different LFG models. Considering the $21^{\text {st }}$ year is final year of waste placement, all models show peak methane gas generation in the end of waste placement. The peak of the graph demonstrates final waste placement for all models. Between the first and final year of deposition of waste, LFG production from the site is increased with increasing degradation of compounds. Tabasaran \& Rettenberger and LandGEM models, predicting more gas generation as compared to TNO and Multi-phase models, seem to overestimate the methane emission. TNO and Multi-phase models, which are based on similar approach, have predicted lower gas volumes. The differences in trends with time are caused by the different estimation theories of the LFG models.

Table 7. The total and remaining LFG potential calculated by models

\begin{tabular}{|c|c|c|}
\hline \multirow{2}{*}{ Model } & \multicolumn{2}{|c|}{ LFG Potential $\left(\mathbf{x 1 0}^{\mathbf{9}} \mathbf{~ m}^{\mathbf{3}}\right)$} \\
\cline { 2 - 3 } & $\begin{array}{c}\text { Total } \\
\mathbf{( 1 9 9 3 - 2 0 9 2 )}\end{array}$ & $\begin{array}{c}\text { Remaining } \\
\mathbf{( 2 0 1 6 - 2 0 9 2})\end{array}$ \\
\hline TNO & 0.68 & $0.30(43.7 \%)$ \\
\hline Tab. \& Rett. & 3.76 & $2.60(69.1 \%)$ \\
\hline LandGEM & 5.33 & $3.97(74.5 \%)$ \\
\hline Multi-Phase & 2.34 & $1.09(46.4 \%)$ \\
\hline
\end{tabular}

With considering the fact that all fractions of waste stream do not decompose at similar rates and overestimates by Tabasaran \& Rettenberger and LandGEM models, Multi-phase model, dividing waste stream into three fractions (i.e. fast, moderate and slow) based on biodegradation rate, was chosen as the LFG model for the subsequent calculations.

Remaining LFG potentials, calculated based on gas volumes between the years 2016 to 2092 , indicates that remaining LFG / methane capacity of the site is nearly 50\%. Thus it can be concluded that energy recovery can be an option for the site for current potentials.

In this study, it's assumed that the landfill site closed in 2020. In LFG modeling, LFG was estimated for a longer period of time (i.e. 100 years) from 1993 to 2092 in order to assess the total LFG potential. But as seen in Figure 1, the economic feasible lifespan of LFG energy recovery project, was ended at almost 2050 . So, remaining energy potential for the site was assessed for the period of 2016 - 2050. Total LFG potential for this period was calculated as $\underline{0.96 \text { billion } \mathrm{m}^{3} \mathrm{LFG}}$. 


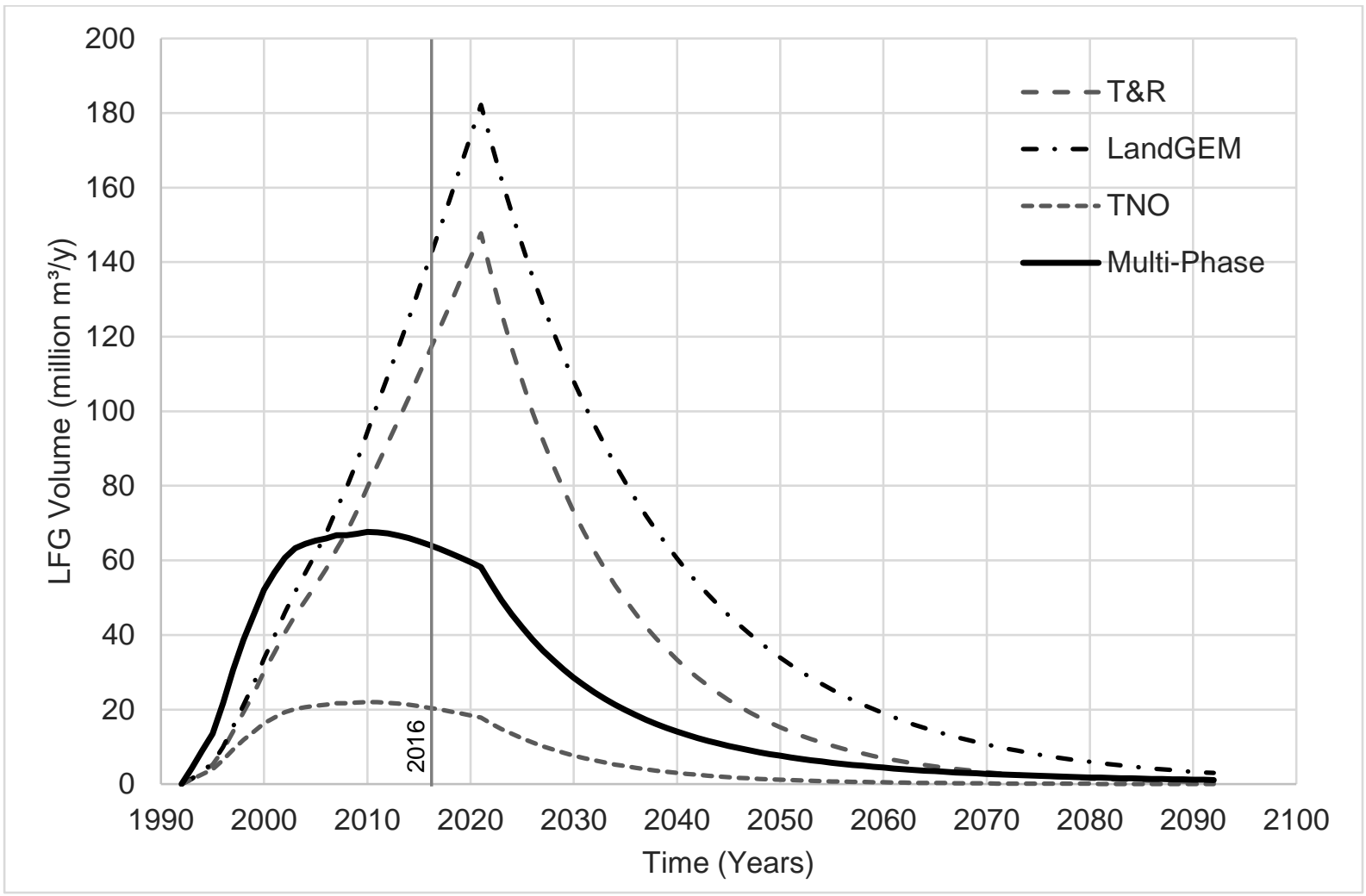

Figure 1. Variation of LFG generation with time obtained by using selected models

LFG is classified as a medium heating value gas with a heating value of about $18.3 \mathrm{MJ} / \mathrm{m}^{3}$ about half that of natural gas [12]. But, LFG generated at Harmandalı Landfill Site was considered as low or medium quality landfill gas due to problems in gas collection system of the site. Energy potential for low and medium quality landfill gases are given as $16 \mathrm{MJ} / \mathrm{m}^{3}$ LFG or $4.4 \mathrm{kWh} / \mathrm{m}^{3}$ LFG in the current literature [13]. Due to problems in gas collection system at the site, the efficiency of gas collection system was considered as $75 \%$. It's assumed that electrical energy will be produced from LFG; thereby capacity factor for LFG to electricity is $80 \%$ and energy conversion ratio is $30 \%$.

The energy potential for proposed energy recovery system was calculated for maximum yearly energy potential, carried out in 2010 (Figure 1). Gross energy potential from Eq. 5 can be calculated as follows:

GEP $=0.75 \cdot 16 \mathrm{MJ} / \mathrm{m}^{3} \cdot 67.6 \cdot 10^{6} \mathrm{~m}^{3}$

$\mathrm{GEP}=811$ million $\mathrm{MJ} / \mathrm{year}=223$ million $\mathrm{kWh} /$ year

Net energy potential for the same year (Eq. 6):

$\mathrm{NEP}=0.30 \cdot 223 \cdot 10^{6} \mathrm{kWh} /(0.8 \cdot 8760)=9547.3 \mathrm{~kW}=\mathbf{9 . 6} \mathrm{MW}$

Maximum energy potential of the site was calculated as 9.6 MW.

\section{KAYNAKLAR}

[1] SCS Eng. \& Augenstein D. (1997): Comparison of Models for Predicting Landfill Methane Recovery (Final Report). Prepared for the Solid Waste Association of North America. 
[2] USEPA (2015): LFG Energy Project Development Handbook. Landfill Methane Outreach Program, https://www3.epa.gov/lmop/.

[3] Kamalan H., Sabour M., Shariatmadari N. (2011): A Review on Available Landfill Gas Models. Journal of Environ. Science \& Tech., Vol: 4, No:2, p. 79-92, ISSN 1994-7887.

[4] Alpaslan N., Dölgen D., Eker S., Seyfioğlu R., Boyacioğlu H., Sarptaş H. (2011): Investigation of Landfill Gas Disposal and Evaluation Alternatives in İzmir Harmandal Landfill Site. Project Final Report (in Turkish).

[5] Swedish Environmental Protection Agency (SEPA) (1999): Gas Emission from Landfills: An overview of issues and research needs. ISSN 1102-6944.

[6] Can C., Alten A. (2011): Comparison of Landfill Gas Generation Models for Solid Waste Landfill Sites. WRECC 2011, http://wreeec2011bali.com/

[7] Scharff H., Jacobs J. (2006): Applying Guidance for Methane Emission Estimation for Landfills. Waste Management 26 (2006) 417-429.

[8] Oonk, H. (2010): Literature Review: Methane from Landfills. Oonkay.

[9] CRA (2009) Landfill Gas Generation Assessment Procedure Guidelines. Prepared for British Colombia Ministry of Environment.

[10] Turkish State Meteorological Service (2014): Precipitation Statistics. www.mgm.gov.tr

[11] Sarptaş, H., Eker, S., Seyfioğlu, R., Boyacıoğlu, H., Dölgen, D., Alpaslan N. (2012) Models for the Prediction of Landfill Gas Potential - A Comparison. Proceedings of The International Conference on Recycling and Reuse 2012. İstanbul.

[12] Dudek, J.; Klimek, P.; Kolodziejak, G.; Niemczewska, J.; Zaleska-Bartosz, J. (2010): Landfill Gas Energy Technologies. Instytut Nafty i Gazu.

[13] SGC (2012): Basic Data on Biogas. Svenskt Gastekniskt Center AB. $2^{\text {nd }}$ edition, ISBN: 978-91-85207-10-7. 